\title{
Estudo farmacognóstico das folhas de Pimenta pseudocaryophyllus (Gomes) L.R. Landrum - Myrtaceae
}

\author{
Joelma A. M. Paula, ${ }^{* 1}$ José R. Paula, ${ }^{2}$ Maria T. F. Bara, ${ }^{2}$ Maria H. Rezende, ${ }^{3}$ \\ Heleno D. Ferreira
}

\author{
${ }^{1}$ Universidade Estadual de Goiás, Unidade Universitária de Ciências Exatas e Tecnológicas, Curso de Farmácia, \\ Caixa Postal 459, 75000-000 Anápolis-GO, Brasil, \\ ${ }^{2}$ Universidade Federal de Goiás, Faculdade de Farmácia, Setor Universitário, 74605-220 \\ Goiânia-GO, Brasil, \\ ${ }^{3}$ Universidade Federal de Goiás, Instituto de Ciências Biológicas, Campus Samambaia, Caixa Postal 131, \\ 74001-970 Goiânia-GO, Brasil
}

\begin{abstract}
RESUMO: O intuito deste trabalho de pesquisa foi obter parâmetros de controle de qualidade para a identificação da matéria-prima vegetal (folha) de Pimenta pseudocaryophyllus (Gomes) L. R. Landrum - Myrtaceae que ocorre no cerrado brasileiro. Para tanto foram coletadas amostras em Minas Gerais - Brasil e no Distrito Federal - Brasil e as exsicatas foram depositadas no Herbário da UFG n. UFG-27.159 e no Herbário Ezechias Paulo Heringer n. 21.745-0, respectivamente. Parte desse material botânico foi preparada para análises macro e microscópicas. Outra parte foi seca, triturada e usada para a triagem fitoquímica. O estudo mostrou que as folhas de $P$. pseudocaryophyllus são hipoestomáticas, têm grande quantidade de tricomas unicelulares na superfície abaxial, têm cavidades secretoras contendo compostos lipídicos e as células epidérmicas possuem paredes celulares espessas. Na triagem fitoquímica foram detectados compostos fenólicos, taninos e flavonóides. Os taninos foram dosados por diferentes métodos envolvendo reações colorimétricas e de precipitação com proteínas. Os diferentes resultados verificados chamam a atenção para a necessidade de se especificar o método utilizado juntamente com o limite mínimo de taninos totais estabelecido. Os resultados obtidos configuram-se como importantes parâmetros para o controle de qualidade da matéria-prima vegetal e denotam que a espécie em estudo possui um importante potencial fitoterápico que merece ser investigado em estudos farmacológicos e toxicológicos.
\end{abstract}

Unitermos: Controle de qualidade, morfo-anatomia, prospecção fitoquímica, Pimenta pseudocaryophyllus.

\begin{abstract}
Pharmacognostic study about Pimenta pseudocaryophyllus (Gomes) L. R. Landrum leaves - Myrtaceae". The goal of this research was to obtain quality control parameters for the identification of the plant drug of Pimenta pseudocaryophyllus (Gomes) L. R. Landrum that occurs in Brazilian savannah. So, two samples were collected, one in Minas Gerais state - Brazil, and the other one in Brasilia city - DF - Brazil, and the vouchers were deposited in the UFG Herbarium code number UFG-27159 and Ezechias Paulo Heringer Herbarium code number 21745-0, respectively. Part of the botanical material in both samples was prepared for microscopic analysis. The other one was air-dried, crushed to powder and used for phytochemical screening. The study has shown that $P$. pseudocaryophyllus leaves are hypostomatic, there are abundant unicellular trichomes in abaxial surface, there are secretory cavities with oily content and epidermal cells have thick wall. Tannins, phenolic compounds and flavonoids were detected in the phytochemical screening. The tannins had been quantified by different methods involving colorimetric and protein precipitation reactions, getting different results. This fact calls the attention for the necessity of specifying the method used together with the minimum tannins limit established. The results configure as important parameters for the quality control of the plant material and denote that the species in study take an important potential as herbal medicine that it deserves to be investigated in pharmacologic and toxicologic studies.
\end{abstract}

Keywords: Quality control, morpho-anatomy, phytochemical screening, Pimenta pseudocaryophyllus. 


\section{INTRODUÇÃO}

O cerrado, dentro da biodiversidade brasileira, é fonte de muitas espécies vegetais que desempenham importante papel na medicina popular (Rodrigues \& Carvalho, 2001). Neste cenário destacam-se espécies da família Myrtaceae, uma das mais importantes famílias da flora brasileira, com 23 gêneros e aproximadamente 1000 espécies (Souza \& Lorenzi, 2005).

No mundo todo, a família Myrtaceae compreende aproximadamente 130 gêneros com cerca de 4.000 espécies e configura-se como a maior família da ordem Myrtales. Apresenta uma distribuição pantropical, embora possua dois grandes centros de dispersão, um nas Américas e outro na Austrália (Landrum \& Kawasaki, 1997; Judd et al., 1999; Souza \& Lorenzi, 2005).

Essa família possui uma diversidade de espécies com aplicações medicinais já estudadas. Ilustram esta afirmação os trabalhos de Gottlieb et al. (1970), Suárez et al. (2000), Fernández et al. (2001), García et al. (2004), Silveira et al. (2005), Apel et al. (2006) e Biavatti et al. (2007). Vale ressaltar ainda, a ocorrência de espécies dessa família que, por possuírem atividade consagrada na cultura popular ou por terem sido estudadas em pesquisas científicas, fazem parte de Monografias da Farmacopéia Brasileira IV (1996, 2002, 2003) e/ou da World Health Organization (2002), tais como: Eucalyptus globulus Labill., Syzygium aromaticum (L.) Merr. \& Perry, Psidium guajava L., Eugenia uniflora L. e Melaleuca alternifolia (Maiden e Betche) Cheel. (Brandão et al., 2006)

A partir de uma abordagem etnofarmacológica, selecionou-se para este trabalho a espécie Pimenta pseudocaryophyllus (Gomes) L.R. Landrum da família Myrtaceae como objeto de estudo. Esta espécie é conhecida como pau-cravo ou craveiro, ocorre na mata atlântica e de forma rara em regiões de cerrado brasileiro, especialmente cerradão. Possui altura de aproximadamente 4 metros e em certas regiões pode ocorrer como simples arbusto. Apresenta tronco aproximadamente ereto com casca áspera e fissurada. As inflorescências apresentam-se em panícula ou dicásios, de coloração branca e muito perfumadas. Apresenta frutos do tipo baga subglobosa, de polpa suculenta, contendo uma a duas sementes muito duras. Os frutos, quando maduros, adquirem uma coloração muito escura, quase negra (Landrum, 1986; Lorenzi, 2002; The New York Botanical Garden, 2004).

Não foram encontrados na literatura relatos de estudos da aplicação medicinal de $P$. pseudocaryophyllus, porém popularmente no município de São Gonçalo do Abaeté - MG as folhas são utilizadas no preparo de chás para estados gripais. E segundo Nakaoka-Sakita et al. (1994), no município de Campos do Jordão - SP, as folhas são empregadas no preparo de chás calmantes, reguladores da digestão e menstruação.

A utilização racional de plantas com fins terapêuticos pode constituir um importante fator de economia no setor de saúde em países em desenvolvimento (Yunes et al., 2001; Funari \& Ferro, 2005). É premente a necessidade de pesquisas que envolvam o uso de plantas medicinais consagradas no meio popular (Elisabetsky \& Souza, 2004; Albuquerque \& Hanazaki, 2006; Agra et al., 2007). Estas pesquisas devem envolver a identificação rigorosa da planta e estabelecer os parâmetros de qualidade necessários a sua utilização a fim de garantir o seu uso seguro, a detecção de fraudes e evitar intoxicações ou efeitos colaterais relacionados a doses inadequadas ou ao uso de plantas erroneamente identificadas (Farias, 2004). O objetivo deste trabalho, portanto, foi fornecer subsídios farmacognósticos para o estabelecimento dos parâmetros de controle de qualidade da matéria-prima vegetal (folha) de P. pseudocaryophyllus.

\section{MATERIAL E MÉTODOS}

\section{Descrição morfo-anatômica}

Para o presente estudo foram utilizadas folhas jovens e adultas da espécie Pimenta pseudocaryophyllus, coletadas em dois municípios: São Gonçalo do Abaeté -

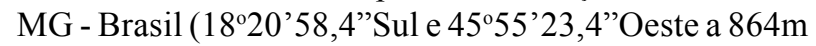
de altitude) e Brasília - DF - Brasil (1551'51,6”Sul e $47^{\circ} 49^{\prime} 43,0^{\prime \prime}$ Oeste a $767 \mathrm{~m}$ de altitude). As folhas jovens foram coletadas do primeiro ao terceiro nó, contados a partir do ápice do ramo, e as folhas adultas, completamente expandidas, foram coletadas abaixo do terceiro nó.

A coleta do material botânico no município de São Gonçalo do Abaeté foi realizada pelo Professor Dr. José Realino de Paula em julho de 2000 por volta de meio dia. O material botânico foi identificado pela Professora Ph.D. Carolyn Elinore Barnes Proença, especialista em Myrtaceae e curadora do Herbário da Universidade de Brasília - UB e encontra-se depositado no Herbário da Universidade Federal de Goiás sob o número UFG-27.159.

A segunda coleta foi realizada no Jardim Botânico de Brasília - DF em abril de 2005 às 10 horas da manhã, de plantas jovem e adulta em estado de frutificação. A exsicata do material botânico foi depositada no Herbário Ezechias Paulo Heringer do Jardim Botânico de Brasília sob o número 21.745-0 e a planta já se encontrava identificada por especialistas da instituição.

\section{Descrição macroscópica}

A caracterização macroscópica das folhas foi realizada à vista desarmada e por meio de observação com o auxílio de microscópio estereoscópico, quando necessário, segundo os parâmetros descritos por Oliveira et al. (1998) e por Oliveira \& Akisue (2000). 


\section{Descrição microscópica}

Utilizando-se uma média de 5 folhas diferentes de cada espécime foram feitas secções de aproximadamente $1,0 \times 0,5 \mathrm{~cm}$ na folha fresca, à mão livre, das seguintes regiões da lâmina foliar: nervura principal, região internervural e bordos. $\mathrm{Na}$ região mediana do pecíolo foram feitas secções de aproximadamente $0,5 \mathrm{~cm}$. Estas secções foram fixadas em FPA [formaldeído a 37\%, ácido propiônico e etanol a $70 \%$ na proporção de $1: 1: 18-(\mathrm{V} / \mathrm{V})]$ por 3 dias (Johansen, 1940) e posteriormente armazenados em etanol a $70 \%(\mathrm{~V} / \mathrm{V})$.

Foram realizados cortes transversais, à mão livre e com o auxílio de micrótomo de mesa. Estes cortes foram submetidos ao processo de dupla coloração Azul de Alcian/ Safranina (9:1) e montados em lâmina com glicerina a $50 \%(\mathrm{~V} / \mathrm{V})$ conforme técnica adaptada de Bukatsch (1972). Os cortes paradérmicos da lâmina foliar, preparados à mão livre, foram tratados conforme descrito anteriormente.

As fotomicrografias referentes às estruturas anatômicas foram feitas em fotomicroscópio modelo ZEISS-AXIOSKOP, com utilização de filme fotográfico Kodacolor ASA 100. As escalas que acompanham as ilustrações foram obtidas nas mesmas condições ópticas. Alguns cortes histológicos foram submetidos à luz polarizada a fim de evidenciar constituintes celulares de natureza cristalina.

\section{Ensaios gerais, prospecção fitoquímica e doseamentos}

Para estas determinações foram coletadas folhas de P. pseudocaryophyllus nos mesmos indivíduos descritos anteriormente e em épocas do ano coincidentes com os períodos de frutificação e floração do vegetal. As amostras coletadas foram dessecadas em estufa com ventilação forçada a $40{ }^{\circ} \mathrm{C}$ e, em seguida, trituradas em moinho de facas. O pó assim obtido foi devidamente identificado, acondicionado e armazenado até sua utilização nos experimentos.

A umidade, cinzas totais e cinzas insolúveis em ácido clorídrico foram realizadas em triplicata, conforme Farmacopéia Brasileira IV (1988). O cálculo das médias foi acompanhado do respectivo desvio padrão e erro padrão da média.

A prospecção fitoquímica das principais classes de metabólitos secundários presentes nas folhas foi realizada utilizando metodologias adaptadas de Matos (1997), Matos \& Matos (1989) e Costa (2001).

Para o doseamento de fenóis totais utilizou-se metodologia descrita por Mole \& Waterman (1987a,b). Os taninos foram dosados por meio de metodologias descritas por Mole \& Waterman (1987a,b) e pela Farmacopéia Brasileira IV (2002) nas monografias das plantas Barbatimão (Stryphnodendron adstringens (Martius) Coville) e Espinheira Santa (Maytenus ilicifolia Mart. ex Reissek), sendo que utilizou-se ainda a mesma metodologia do Barbatimão substituindose o pó-de-pele por caseína a fim de verificar se esta última, de custo mais baixo, apresentava resultados semelhantes. Os flavonóides foram dosados utilizandose a metodologia descrita na Farmacopéia Brasileira IV (2001) na monografia da planta Calêndula (Calendula officinalis L.). Todas as metodologias foram realizadas em triplicata e o cálculo das médias foi acompanhado dos respectivos desvio padrão e erro padrão da média. Para comparar as médias e avaliar possíveis diferenças nos teores dos metabólitos secundários referentes ao período fenológico e à localidade geográfica do vegetal foi utilizado o teste t-student ao nível de $5 \%$ de significância.

\section{RESULTADOS}

\section{Descrição macroscópica}

As folhas dos espécimes de Pimenta pseudocaryophyllus coletadas nas duas localidades são simples, curtamente pecioladas (Figura 1), opostas cruzadas e coriáceas. O limbo foliar é inteiro, a lâmina foliar é elíptica a oval. Medem de $10-22 \mathrm{~cm}$ x $5-9 \mathrm{~cm}$. O ápice é obtuso a acuminado e até levemente emarginado. A base foliar é cuneada. Apresentam-se glabras na superfície adaxial com coloração verde escura brilhante, pilosas na superfície abaxial com coloração amarelada devido à presença dos numerosos tricomas, portanto são discolores. Quanto à nervação são peninérvias, com as nervuras primária e secundárias salientes na face abaxial e impressas na face adaxial. O padrão de nervação é do tipo camptódromo-broquidódromo, onde as nervuras secundárias se anastomosam desde a base da folha e formam uma série de arcos próximos ao bordo, sendo que no espécime de Brasília estes arcos são mais definidos e nítidos (Figura 2) e no espécime de São Gonçalo do Abaeté estes arcos tornam-se mais definidos das proximidades da região mediana da folha até o ápice (Figura 3). O pecíolo é cilíndrico ou levemente côncavoconvexo medindo de 0,5 a 2,0 cm de comprimento.

As folhas, quando verificadas contra a luz, apresentam vários pontos transparentes espalhados, caracterizando a presença de cavidades secretoras de substâncias terpênicas dispostas ao longo do mesofilo que quando amassadas entre os dedos liberam um odor característico.

\section{Descrição microscópica}

\section{Lâmina foliar}

Epiderme: A epiderme adaxial da folha adulta de P. pseudocaryophyllus coletada em Brasília acha-se constituída por células que, em vista frontal, revelam dimensões variadas e paredes anticlinais espessas, 
predominantemente retas a onduladas (Figura 4). Foi possível notar regiões constituídas por duas ou, mais raramente, três células centrais circundadas radialmente por células epidérmicas menores, tais regiões correspondem aos elementos que recobrem as cavidades secretoras (Figura 4). Na face adaxial não foram registrados estômatos e tricomas, porém há regiões nas quais as células epidérmicas dispõem-se radialmente se assemelhando ao posicionamento assumido ao redor da base de um tricoma (Figura 4). Tratam-se de cicatrizes deixadas após a queda destes tricomas, pois verificouse que a epiderme adaxial da folha jovem é rica em tricomas (Figura 5).

A epiderme abaxial apresenta-se rica em estômatos, que são predominantemente anomocíticos, e tricomas tectores unicelulares alongados (Figura 6). A presença de tricomas em grande quantidade e a espessa camada de cutícula que reveste a epiderme abaxial dificultaram a análise e caracterização dos tipos de estômatos.

As paredes anticlinais das células da epiderme abaxial, em vista frontal, apresentam-se espessas e sinuosas (Figura 6). As células que revestem as cavidades secretoras são menos freqüentes que na superfície adaxial (Figura 7).

Região intercostal e bordo: Em secção transversal, a lâmina foliar de ambos os espécimes apresenta estrutura tipicamente dorsiventral e hipoestomática (Figuras 8 e 9). A epiderme da face adaxial é uniestratificada seguida por uma hipoderme formada de células um pouco maiores dispostas em duas ou três camadas. Em ambos os espécimes observou-se uma espessa camada de cutícula revestindo a epiderme adaxial e abaxial. Não foi possível, com o uso de microscopia óptica, a verificação de estrias epicuticulares, porém é clara a formação de flanges na epiderme adaxial (Figuras 9).

Em ambos os espécimes verificou-se, imersas na hipoderme, próximo à superfície adaxial e atingindo o parênquima paliçádico, inúmeras cavidades secretoras esquizógenas (Figuras 8 e 10). Estas cavidades aparecem predominantemente próximas à superfície adaxial e em menor freqüência na abaxial. Em seções transversais, observa-se que entre a cavidade secretora e as células epidérmicas, ocorrem pares ou, com menor freqüência, trios de células achatadas com paredes delgadas e portadoras de substâncias fenólicas, que compõem a porção superior desta estrutura secretora (Figura 10). As cavidades são ricas em conteúdo lipídico.

O mesofilo está representado, em ambos os espécimes, pelos parênquimas paliçádico e lacunoso (Figuras 8 e 9). O parênquima paliçádico é formado por células alongadas compactamente dispostas em duas ou três camadas. O parênquima lacunoso é formado por células globosas frouxamente distribuídas em aproximadamente seis camadas. Ao longo do mesofilo, principalmente na região do parênquima lacunoso, há uma enorme quantidade de idioblastos portadores de cristais prismáticos ou drusas que aparecem de forma mais abundante no espécime de São Gonçalo do Abaeté - MG (Figuras 8, 10 e 11).

Em ambos os espécimes, as nervuras de médio e pequeno porte estão localizadas nos limites do paliçádico com o lacunoso. As nervuras mais desenvolvidas têm os tecidos de condução guarnecidos por um anel de natureza esclerenquimática, comunicando-se com os elementos epidérmicos através de extensões de bainha de colênquima angular (Figuras 8, 9 e 12).

O bordo foliar, em ambos os espécimes analisados, apresenta-se levemente fletido em direção à face abaxial e com presença de cavidades secretoras (Figura 13). Há, nesta região, um espessamento maior da cutícula evidenciando-se flanges que se prolongam por toda a extensão das paredes anticlinais (Figura 13). $\mathrm{O}$ mesofilo, à medida que se aproxima do bordo, exibe uma mudança gradativa do tamanho e formato das células, até ser substituído por um colênquima do tipo angular (Figuras 13). São raros os grãos de amido ao longo do mesofilo.

Nervura Principal: A seção transversal, ao nível do terço mediano da nervura principal, demonstra que o espécime coletado em Minas Gerais apresenta nervura principal mais desenvolvida (Figuras 14 e 15).

Em ambos os espécimes a epiderme adaxial e abaxial é uniestratificada recoberta por espessa camada de cutícula. Tricomas tectores unicelulares estão presentes apenas na epiderme abaxial. Colênquima angular é registrado em ambas as faces contendo muitas cavidades secretoras. O parênquima cortical é formado por células arredondadas de parede delgada e com alta freqüência foram observados idioblastos portadores de drusas de oxalato de cálcio (Figuras 14 e 15).

O sistema vascular se apresenta na forma de arco com as extremidades bem abertas, com disposição bicolateral, sendo o floema organizado de forma compacta e contínua interna e externamente ao xilema. A região perivascular é constituída por uma bainha esclerenquimática (Figuras 14 e 15). No espécime de Minas Gerais células parenquimáticas do floema externo possuem cristais de oxalato de cálcio de diferentes formatos formando séries cristalíferas. Estes cristais aparecem de forma esparsa no floema externo do espécime de Brasília.

\section{Pecíolo}

Em cortes transversais da região mediana do pecíolo, de ambos os espécimes analisados, observase que o mesmo apresenta formato aproximadamente circular, porém encontra-se mais desenvolvido no espécime coletado em Minas Gerais (Figuras 16 e 17).

A epiderme é uniestratificada recoberta por espessa cutícula. Os estratos cuticulares espessos formam flanges. São observados ainda, tricomas tectores unicelulares. 
A região correspondente ao córtex é preenchida por células parenquimáticas de paredes espessas que exibem um caráter colenquimatoso, com espessamentos variáveis. O córtex do espécime de Brasília apresenta um elevado número de idioblastos portadores de drusas de oxalato de cálcio, ao passo que o de Minas Gerais os apresenta em número menor. Em ambos os espécimes ocorrem cavidades secretoras na região subepidérmica idênticas as já descritas para a lâmina foliar (Figuras 16 e 17).

O sistema vascular está organizado na forma de arco e é do tipo bicolateral. O floema externo do espécime de Minas Gerais apresenta células parenquimáticas portadoras de cristais de oxalato de cálcio de diferentes formatos dispostos em séries cristalíferas. Estas séries cristalíferas são evidentes tanto no floema externo quanto no interno do espécime de Brasília (Figuras 16 e 17).

Teores de umidade, cinzas totais e cinzas insolúveis em ácido clorídrico

Os teores de umidade, cinzas totais e cinzas insolúveis em ácido clorídrico para os dois espécimes analisados são apresentados na Tabela 1 .

\section{Prospecção fitoquímica}

Os resultados dos testes fitoquímicos para detecção das principais classes de metabólitos secundários estão expressos na Tabela 2.

\section{Doseamento dos grupos relevantes na prospecção}

Os resultados dos doseamentos de flavonóides, fenóis totais e taninos dos espécimes analisados encontram-se nas Tabelas 3 e 4 .

\section{DISCUSSÃO}

\section{Caracteres morfo-anatômicos}

As características macroscópicas da folha dos espécimes analisados neste trabalho estão em conformidade com o que descrevem Joly (1979) e Judd et al. (1999) para Myrtaceae. A análise da arquitetura das folhas também mostra que as mesmas se enquadram na morfologia descrita por Landrum (1986). O padrão de nervação foliar camptódromo-broquidódromo observado, apesar de não ser considerado o tipo predominante nesta família, foi descrito também por Cardoso \& Sajo (2004) para espécies do gênero Eugenia da família Myrtaceae. A Farmacopéia Brasileira IV (2002) descreve este mesmo padrão de venação para a espécie Psidium guajava L. (goiabeira).

No que concerne aos aspectos anatômicos da lâmina foliar e do sistema vascular, segundo Solereder
(1908) as Myrtaceae são caracterizadas pela ocorrência de cavidades secretoras esquizógenas e por possuírem floema interno. Tais características foram evidenciadas nos espécimes analisados.

As células da epiderme adaxial das folhas dos espécimes analisados apresentam paredes anticlinais espessas, predominantemente retas a onduladas. Segundo Gomes \& Neves (1993/1997) o contorno das paredes anticlinais das células epidérmicas pode exibir variações nas Myrtaceae.

As estruturas secretoras do mesofilo de Pimenta pseudocaryophyllus de ambas as localidades são evidenciadas na epiderme, em vista frontal, principalmente na superfície adaxial, pela presença de duas ou três células que se distinguem das demais por apresentarem cromatismo mais tênue e menor sinuosidade parietal. Tais células fazem parte de um conjunto secretor que merece maiores estudos. Com freqüência os trabalhos envolvendo estudos morfoanatômicos de Myrtaceae fazem alusão a este complexo secretor tais como Callado (1993/1997), Gomes \& Neves (1993/1997) e Fontenelle et al. (1994). Os últimos autores denominam as células deste conjunto secretor de OLC (overlying cells) e destacam o valor diagnóstico das mesmas.

Os tricomas simples e longos evidenciados nos espécimes analisados são segundo Metcalfe \& Chalk (1979), muito comuns nas Myrtaceae e dão uma sensação de maciez ao tocar a superfície na qual eles são abundantes. Eles podem aparecer somente em uma das superfícies da folha ou em ambas.

Os tricomas tectores simples cobrem densamente apenas a superfície abaxial das folhas adultas dos espécimes de $P$. pseudocaryophyllus analisados neste trabalho. Estes achados são registrados também por Landrum \& Kawasaki (1997). Vale ressaltar que as cicatrizes de tricomas encontradas na superfície adaxial glabra desta espécie indicam que haviam tricomas ali em alguma fase da vida deste vegetal e isso pôde ser confirmado por meio das análises em folhas jovens do primeiro, segundo e terceiro nós. As folhas jovens apresentavam tricomas tectores em ambas as superfícies. Tais achados são também registrados por Landrum (1986). Tanto em folhas jovens quanto em adultas, a densidade de tricomas observada dificultou grandemente a observação dos demais elementos da epiderme em vista frontal.

Solereder (1908) relata que as Myrtaceae não apresentam um tipo de estômato característico. Por tratar-se de uma folha hipoestomática e sendo a superfície abaxial densamente coberta por tricomas, a visualização dos tipos de estômatos presentes foi imensamente prejudicada. Porém, é possível afirmar que dentre os tipos descritos por Metcalfe \& Chalk (1979) o que predomina em Pimenta pseudocaryophyllus é o tipo anomocítico.

Em corte transversal da lâmina foliar pôde-se 
verificar que as epidermes adaxial e abaxial parecem ser uniestratificadas seguidas de camadas de células linearmente arranjadas. Não é possível afirmar, porém, que tais células sejam hipoderme ou epiderme múltipla. Metcalfe \& Chalk (1979) afirmam que uma genuína epiderme múltipla, formada ontogeneticamente pelas divisões periclinais de uma camada simples de epiderme não é fácil de distinguir de uma verdadeira hipoderme, formada pela divisão de células subjacentes à epiderme. Faz-se necessário um estudo ontogenético para afirmar com exatidão a origem das células subepidérmicas. É comum na literatura a existência de grande confusão entre epiderme múltipla e hipoderme. Neste trabalho optou-se por denominar a camada subepidérmica de hipoderme, uma vez que não se realizou o estudo ontogenético da referida camada de células.

As inúmeras cavidades secretoras, que aparecem com maior freqüência abaixo da epiderme adaxial, são portadoras de substâncias terpênicas. Solereder (1908) aponta que cavidades secretoras ricas em substâncias terpênicas são características de Myrtaceae.

De um modo geral o mesofilo das espécies de Myrtaceae encontra-se diferenciado em parênquima paliçádico uni ou pluriestratificado e parênquima lacunoso. Parênquima paliçádico pluriestratificado e compacto como o de Pimenta pseudocaryophyllus é mencionado por Fontenelle et al. (1994) para algumas espécies do gênero Eugenia. Estes autores atribuem esta característica, juntamente com a presença de taninos e o fato das células epidérmicas terem paredes anticlinais retas e espessas, a adaptações morfo-fisiológicas aos fatores ambientais, dentre os quais, a alta luminosidade pode ser o mais importante. Estas características xeromórficas também foram registradas nas folhas de Pimenta pseudocaryophyllus, bem como elevada concentração de taninos evidenciada nos ensaios fitoquímicos descritos neste trabalho.

Solereder (1908) relata a ocorrência de cristais agrupados ou solitários no mesofilo das Myrtaceae. Em ambos os espécimes analisados há uma grande quantidade de idioblastos portadores de cristais agrupados do tipo drusas. Séries de cristais solitários de diferentes formatos foram registrados no parênquima floemático das nervuras principais e pecíolos dos espécimes analisados. Metcalfe \& Chalk (1979) abordam que alguns taxa variam de acordo com os tipos de cristais das células do parênquima floemático e na distribuição destas células. Sendo assim, os cristais, no floema, podem estar localizados em linhagens de células cristalíferas especializadas as quais são menores que as células ordinárias do parênquima e geralmente possuem um único cristal.

O sistema vascular, do tipo bicolateral, observado na nervura principal e no pecíolo é relatado também por Gomes \& Neves (1993/1997) para espécies do gênero Gomidesia da família Myrtaceae. Porém, nas espécies que estes autores analisaram o floema organiza- se em grupos dispostos em torno do xilema. Em Pimenta pseudocaryophyllus o floema distribui-se continuamente em torno do xilema. Este padrão de distribuição do floema é relatado na Farmacopéia Brasileira IV (2002, 2003) para as folhas das Myrtaceae Psidium guajava L. (goiabeira) e Eugenia uniflora L. (pitangueira). Nestas espécies há também um anel de fibras envolvendo o sistema vascular na nervura principal tal como ocorre em Pimenta pseudocaryophyllus.

\section{Prospecção fitoquímica, ensaios gerais e doseamentos}

As amostras de P. pseudocaryophyllus coletadas em Brasília apresentaram 10,66\% (p/p) e 7,81\% (p/p) de teor de umidade. As coletadas em Minas Gerais apresentaram teores de umidade de 7,71\% (p/p) e 7,11\% (p/p) (Tabela 1). As matérias-primas vegetais contêm, naturalmente, certa quantidade de água, que se mantém desde a secagem das plantas. É relevante conhecer este valor, pois este índice está relacionado com a correta preparação e garantia da perfeita conservação das drogas vegetais (Costa, 2001). A Farmacopéia Brasileira IV (1988) estabelece limites de 8 a 14\% de umidade para as matérias-primas vegetais, em geral, com algumas exceções especificadas nas monografias.

Quanto ao teor de cinzas totais as amostras coletadas em Brasília apresentaram 6,60\% (p/p) e $3,71 \%(\mathrm{p} / \mathrm{p})$ e as coletadas em Minas Gerais 4,91\% $(\mathrm{p} / \mathrm{p})$ e $4,70 \%(\mathrm{p} / \mathrm{p})$ (Tabela 1). As cinzas, resíduos não voláteis, isentos de carbono, que se originam da combustão das substâncias orgânicas em condições apropriadas, provêm, basicamente, dos constituintes minerais e dos organo-metálicos que integram as plantas (cinzas fisiológicas) e, ainda, de materiais estranhos, especialmente areia e terra aderente à superfície da droga (cinzas não-fisiológicas) (Farmacopéia Brasileira IV, 1988; Costa, 2001). Portanto, o teor de cinzas totais acima do estabelecido como parâmetro para uma determinada matéria-prima vegetal indica presença de impurezas inorgânicas não-voláteis que podem estar presentes como contaminantes (Oliveira et al., 1998; Farias, 2004).

O teor de cinzas insolúveis em ácido clorídrico foi de $0,09 \%(\mathrm{p} / \mathrm{p})$ e $0,14 \%(\mathrm{p} / \mathrm{p})$ para as amostras coletadas em Brasília, e $0,31 \%(\mathrm{p} / \mathrm{p})$ e $0,49 \%$ (p/p) para as amostras coletadas em Minas Gerais (Tabela 1). A determinação de cinzas insolúveis em ácido clorídrico destina-se à detecção de sílica e constituintes silicosos que em quantidade acima da estabelecida para a droga vegetal indica contaminação por excesso de terra ou areia (Farmacopéia Brasileira IV, 1988; Farias, 2004).

Os resultados diferentes nos respectivos teores de cinzas totais e cinzas insolúveis em ácido clorídrico das amostras analisadas podem estar relacionados às condições ambientais e do solo dos diferentes locais de onde foram coletadas, porém fornecem subsídios para 
o estabelecimento de um limite para este parâmetro de qualidade.

Na prospecção fitoquímica pôde-se constatar, como principais metabólitos secundários, a presença de traços de heterosídeos antraquinônicos, além de evidente presença de flavonóides e taninos (Tabela 2).

Tendo em vista tais resultados, procedeuse à quantificação dos compostos fenólicos (Tabela 3 ). As amostras de $P$. pseudocaryophyllus analisadas neste trabalho apresentaram quantidade considerável de compostos fenólicos totais: $9,08 \%(\mathrm{p} / \mathrm{p})$ e $10,52 \%$ $(\mathrm{p} / \mathrm{p})($ Brasília), e 9,77\% (p/p) e 7,37\% (p/p) (Minas Gerais). Os compostos fenólicos contribuem para o sabor e coloração de diversos vegetais, além de muitos deles possuírem atividade antioxidante, antibacteriana e antiviral (Carvalho et al., 2004).

As folhas de $P$. pseudocaryophyllus coletadas em Brasília apresentaram 1,05\% (p/p) e 1,37\% (p/p) de flavonóides totais. As coletadas em Minas Gerais apresentaram $0,90 \%(\mathrm{p} / \mathrm{p})$ e $1,07 \%(\mathrm{p} / \mathrm{p})$ de flavonóides totais, dosados pelo método descrito na monografia da Calêndula (Farmacopéia Brasileira IV, 2001), portanto expressos como hiperosídeo (Tabela 3). Esses valores são expressivos se comparados à matéria-prima vegetal da Calêndula que deve possuir não menos que $0,4 \%$ de flavonóides totais, calculados como hiperosídeo (Farmacopéia Brasileira IV, 2001; WHO, 2002). O Folium Ginkgo (Ginkgo biloba L.) deve conter não menos que $0,5 \%$ de flavonóides calculados como flavonol glicosídeos ou 0,2 - 0,4\% calculados como agliconas (WHO, 1999).

Esses valores são comparativos aos de outras espécies de Myrtaceae: a Goiabeira (Psidium guajava L.), cujas folhas secas devem possuir, no mínimo, 1,0\% de flavonóides totais calculados como quercetina e a Pitangueira (Eugenia uniflora L.) cujas folhas secas devem conter, no mínimo, 2,0\% de flavonóides totais, também calculados como quercetina (Farmacopéia Brasileira IV, 2002, 2003).

Os flavonóides constituem uma importante classe de polifenóis relativamente abundantes e diversificados entre os metabólitos secundários dos vegetais. Há relatos de atividades antitumoral, antiespasmódica, antiinflamatória, antimicrobiana, antimutagênica, antiúlcera, antiviral, antioxidante, estrogênica, giardicida, tripanossomicida, inibidor da enzima acetilcolinesterase e inibidor da enzima conversora de angiotensina, atribuídas a flavonóides. Além disso, ainda são importantes como marcadores taxonômicos devido à sua relativa abundância em quase todo o reino vegetal e sua especificidade em algumas espécies (Wollenweber et al., 2000; Amaral et al., 2001; Zuanazzi \& Montanha, 2004; Amaral et al., 2006; Barbosa-Filho et al., 2006a,b).

As folhas dessecadas de P. pseudocaryophyllus apresentaram quantidades importantes de taninos totais, dosados por diferentes métodos (Tabela 4). Os

valores de $14,56 \%, 15,41 \%, 14,84 \%$ e $12,08 \%$ obtidos pelo método descrito na monografia do Barbatimão são comparativos aos teores de taninos desta mesma espécie descritos na Farmacopéia Brasileira IV (2002) que devem ser de, no mínimo, $8 \%$. Quando se utiliza caseína, de custo mais baixo, em substituição ao pó-depele os valores encontrados decresceram na maioria das amostras analisadas demonstrando que esta proteína não foi comparativa nesta metodologia ao pó-de-pele.

Os teores de taninos totais $(2,67 \%, 5,11 \%$, $3,75 \%$ e $4,04 \%$ ) encontrados com a utilização do método descrito na monografia da Espinheira Santa (Tabela 4) são também expressivos, pois esta planta deve conter, no mínimo, 2\% de taninos totais (Farmacopéia Brasileira IV, 2002).

Os taninos são compostos importantes como componentes gustativos, responsáveis pelo sabor adstringente de vegetais. $O$ fato de complexarem-se com proteínas constitui a base para as suas propriedades. Dentre suas importantes atividades farmacológicas podem-se citar: ação bactericida e fungicida; antiviral; moluscicida; inibição de enzimas bacterianas; inibição da peroxidação de lipídeos e seqüestrador de radicais livres e ação antitumoral (Santos \& Mello, 2004; Souza et al., 2007). Há relatos na literatura de efeitos carcinogênicos e de toxicidade hepática atribuídos aos taninos. Tais efeitos, obviamente, dependem da dose e do tipo de tanino ingerido (Monteiro et al., 2005).

Os resultados obtidos neste estudo no qual foram utilizadas amostras coletadas em duas localidades geográficas diferentes e em estádios de desenvolvimento também diferentes, permitem a elaboração de outras considerações. Após a análise estatística (teste t-student) para comparação das médias obtidas em cada doseamento da matéria-prima vegetal verificou-se, no grupo de amostras analisado, uma diferença significativa entre os teores de flavonóides, sendo que as amostras coletadas em Brasília demonstraram teores superiores, especialmente no período de floração.

Quanto aos teores de fenóis totais e taninos não foi observada diferença significativa entre as duas localidades geográficas em todas as metodologias utilizadas quando a comparação das médias não leva em conta o estádio de desenvolvimento do vegetal. Porém quando a amostra coletada em Brasília no período de floração foi comparada à amostra coletada neste mesmo período em Minas Gerais, foram verificados teores significativamente maiores de fenóis totais e taninos na amostra coletada em Brasília, quando dosadas pelas metodologias de Hagerman \& Butler (Mole \& Waterman, 1987a,b) e do Barbatimão (Farmacopéia Brasileira IV, 2002). Já com a utilização da metodologia da Espinheira Santa (Farmacopéia Brasileira IV, 2002), diversamente, foi verificada uma diferença significativa nos teores de taninos das amostras coletadas no período de frutificação em ambas as localidades, sendo que a de Minas Gerais apresentou teor significativamente maior 


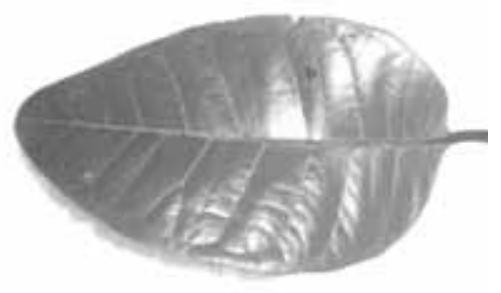

1

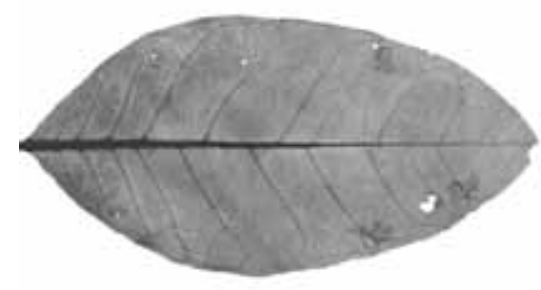

2

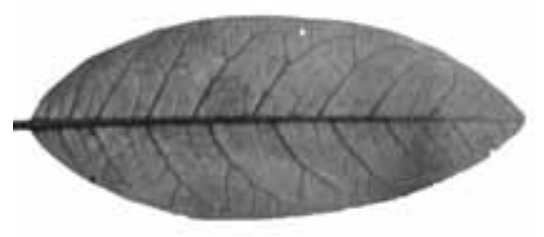

3

Figuras 1-2. Pimenta pseudocaryophyllus coletadas em Brasília - DF: Fig 1, aspecto geral da superfície adaxial da folha. Fig. 2, folha diafanizada demonstrando detalhes do padrão de nervação.

Figura 3. Pimenta pseudocaryophyllus coletada em São Gonçalo do Abaeté - MG: folha diafanizada demonstrando detalhes do padrão de nervação.
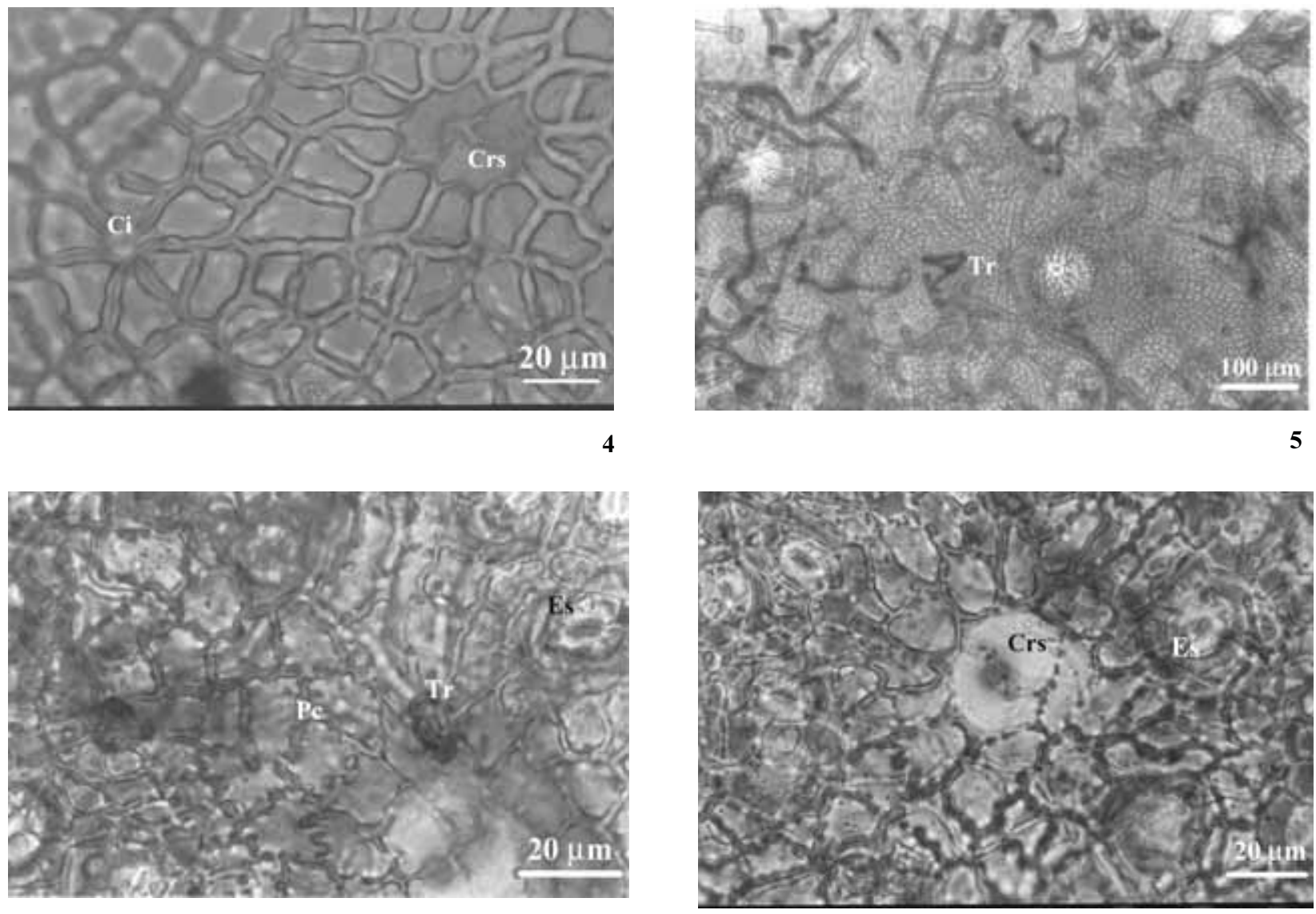

6

Figuras 4-7. Secções paradérmicas da lâmina foliar de Pimenta pseudocaryophyllus coletada em Brasília - DF: Fig. 4, detalhe da epiderme adaxial da folha adulta. Fig. 5, epiderme adaxial da folha jovem. Fig. 6, epiderme abaxial da folha adulta. Fig. 7, detalhe da epiderme abaxial da folha adulta.

Legenda: Crs - Célula que reveste cavidade secretora; Ci - Cicatriz deixada após queda do tricoma tector; Pc - Parede celular; Es - Estômato; Tr - Tricoma tector.

de taninos que a de Brasília.

É de conhecimento geral que as condições ambientais podem provocar variações significativas na produção de metabólitos secundários nos vegetais. Neste sentido são ilustrativos os trabalhos de Santos et al. (2006), Borella et al. (2006); Monteiro et al. (2006) e pesquisas desenvolvidas pelo professor Vicente Casali da Universidade Federal de Viçosa (Fapemig, 2002). 

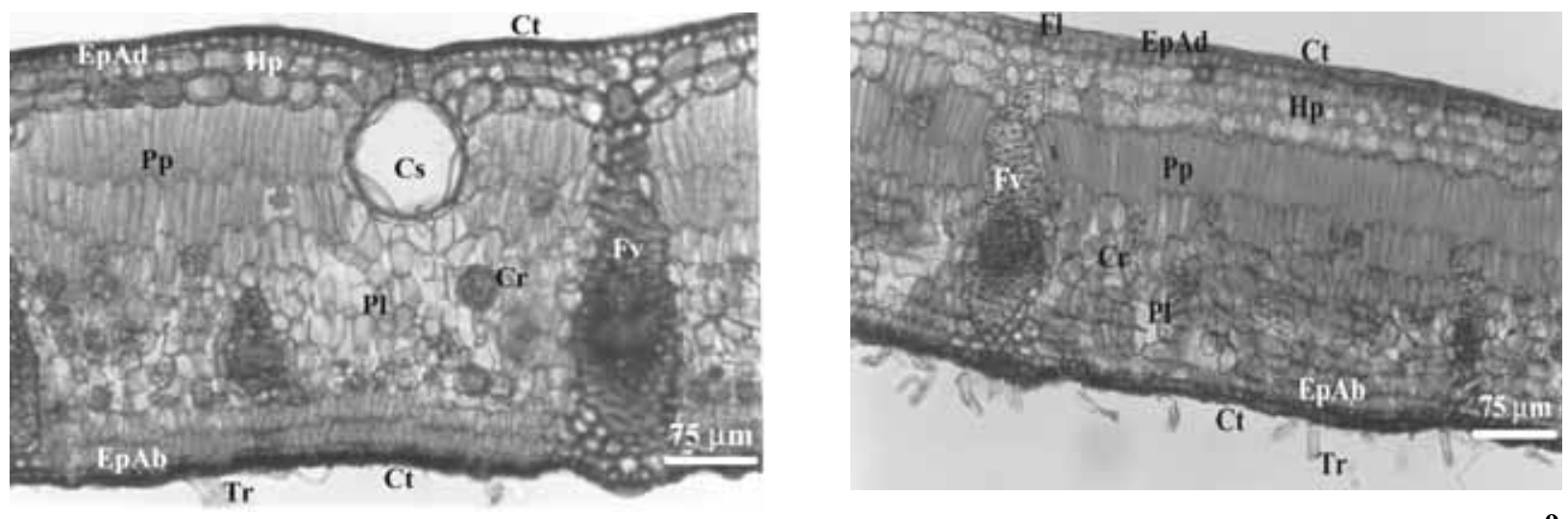

8
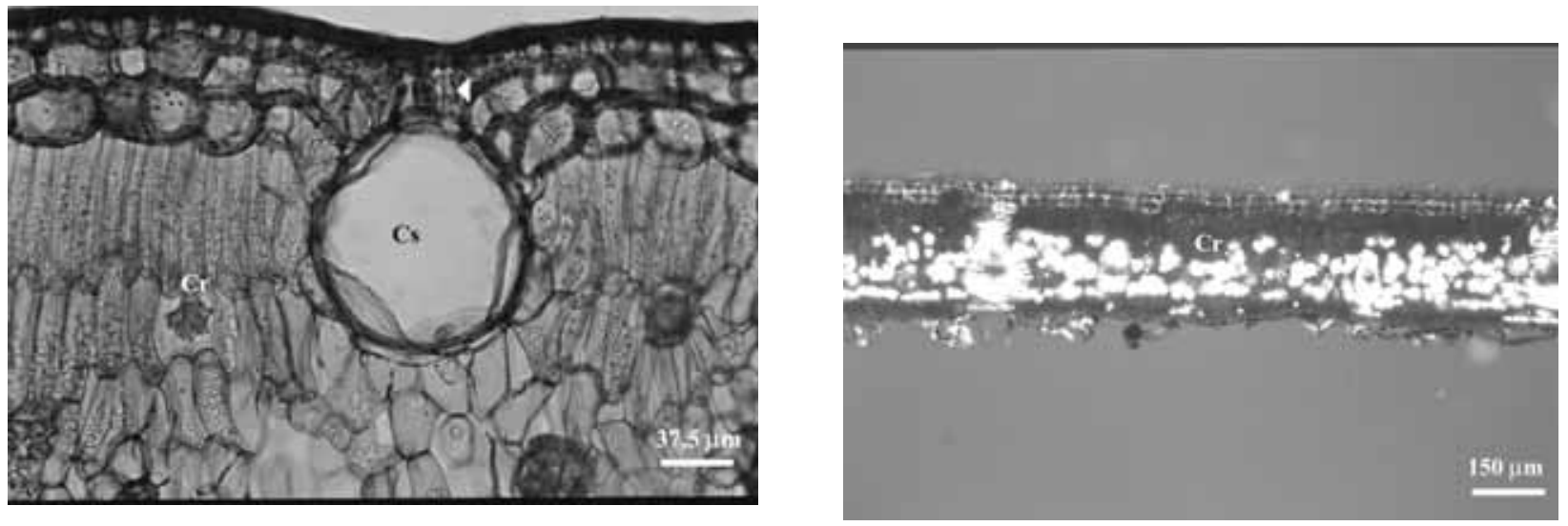

10
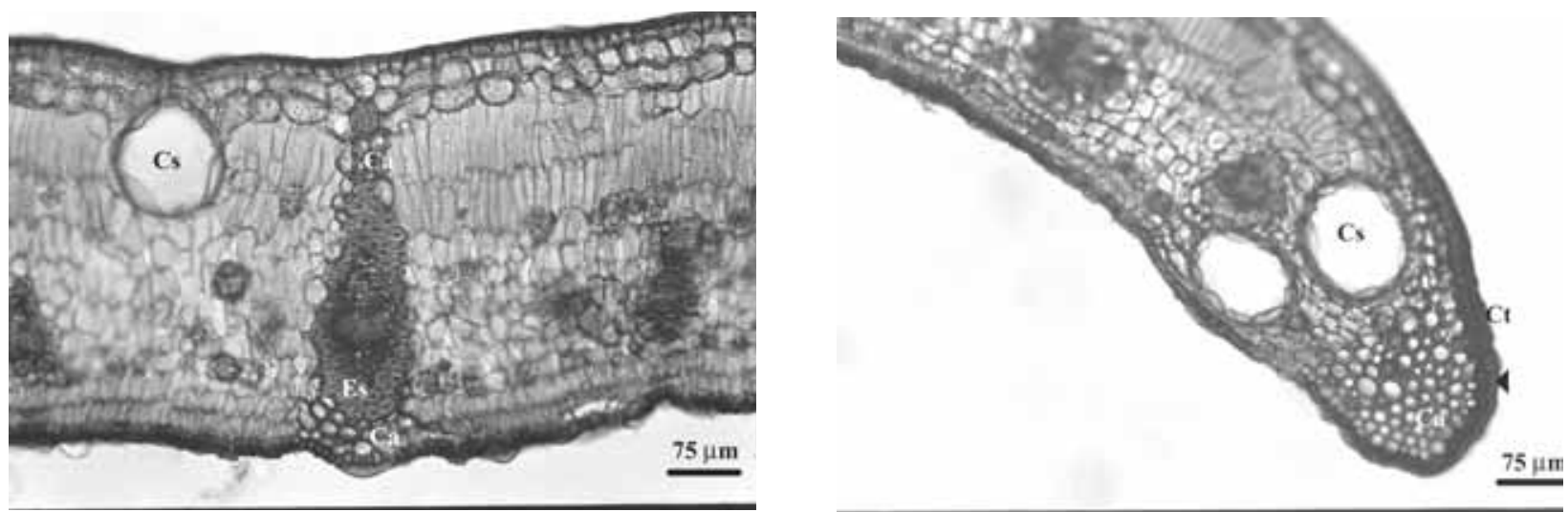

12

Figuras 8-13. Secções transversais da lâmina foliar de Pimenta pseudocaryophyllus - região internervural e bordo: Fig. 8, lâmina foliar do espécime coletado em São Gonçalo do Abaeté - MG. Fig. 9, lâmina foliar do espécime coletado em Brasília - DF. Fig. 10, detalhe da lâmina foliar do espécime coletado em São Gonçalo do Abaeté - MG demonstrando uma cavidade secretora. Fig. 11, lâmina foliar do espécime coletado em São Gonçalo do Abaeté - MG visualizada em luz polarizada. Fig. 12, detalhe de um feixe vascular do espécime coletado em São Gonçalo do Abaeté-MG. Fig. 13, bordo da região basal da lâmina foliar do espécime de São Gonçalo do Abaeté - MG.

Legenda: Ca - Colênquima angular; Cr - Cristais - drusa; Cs - Cavidade secretora; Ct - Cutícula; EpAd - Epiderme adaxial; EpAb - Epiderme abaxial; Es - Esclerênquima; Fl - flange; Fv - feixe vascular; Hp - Hipoderme; Pl - Parênquima lacunoso; Pp - Parênquima paliçádico; Tr - Tricoma tector; 4 , setas indicam as células achatadas que compõem a parte superior da cavidade secretora na Fig. 10 e flanges na Fig. 13. 


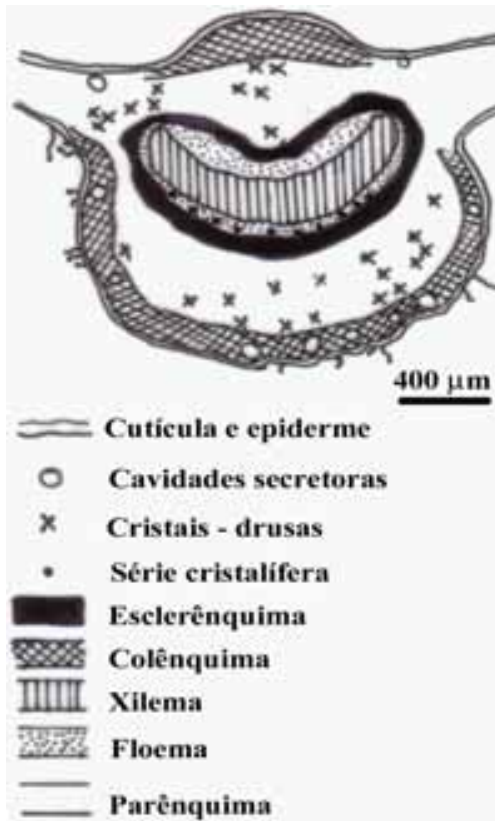

14

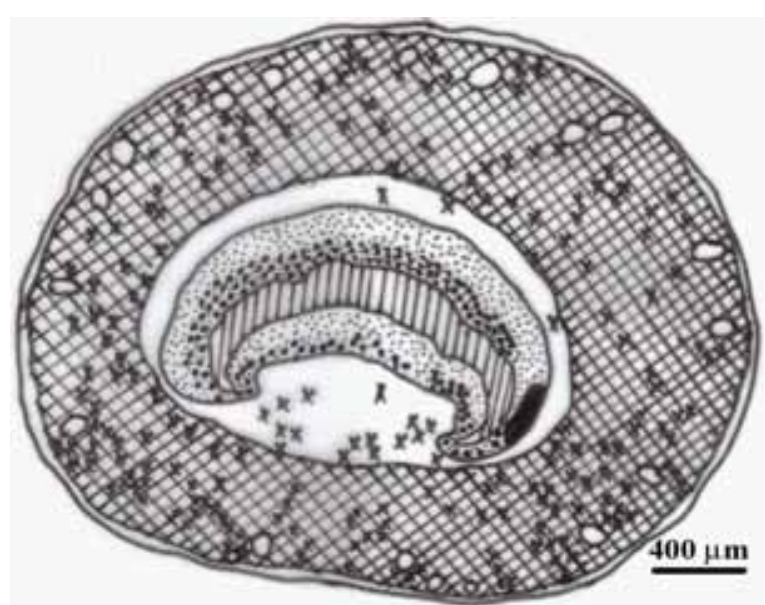

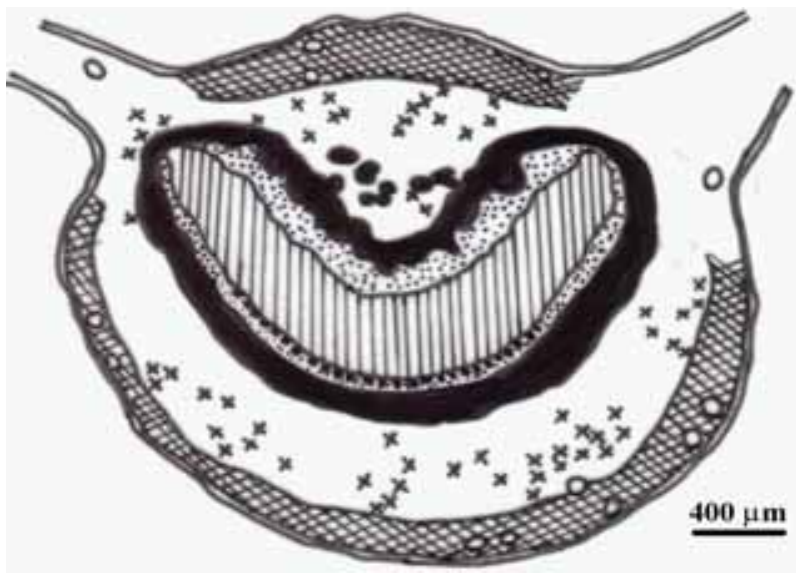

15

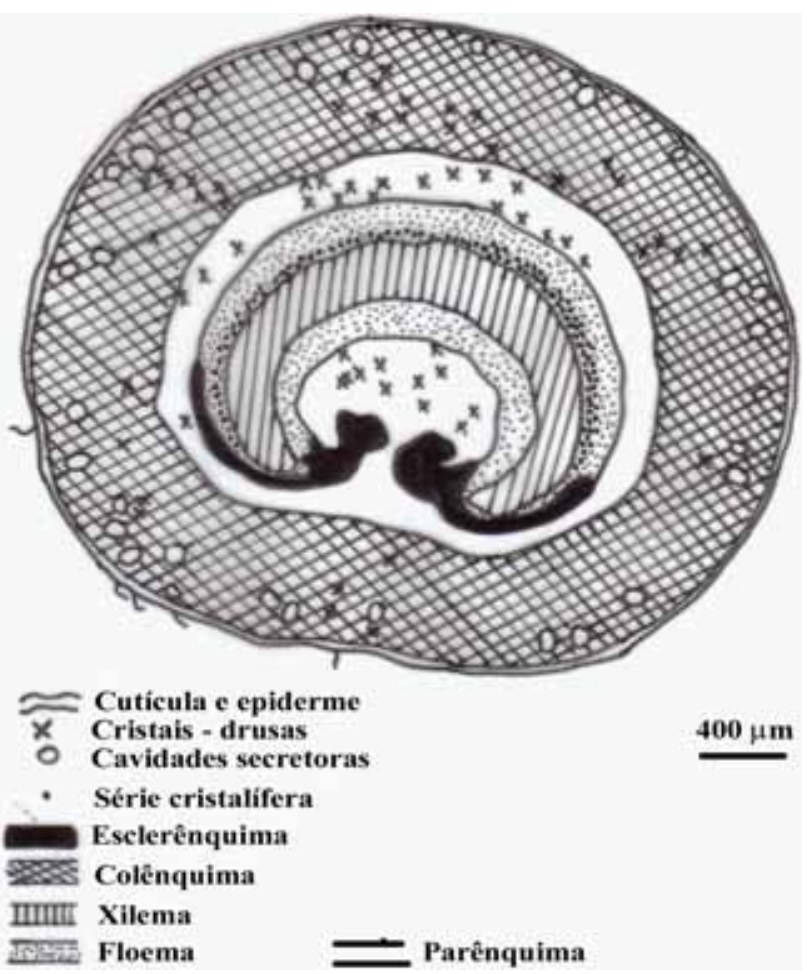

17

Figuras 14-15. Secções transversais da nervura principal da lâmina foliar de Pimenta pseudocaryophyllus: Fig. 14, diagrama da secção transversal da nervura principal do espécime coletado em Brasília - DF. Fig. 15, diagrama da secção transversal da nervura principal do espécime coletado em São Gonçalo do Abaeté - MG.

Figuras 16-17. Secções transversais da região mediana do pecíolo de Pimenta pseudocaryophyllus: Fig. 16, diagrama da secção transversal do pecíolo do espécime coletado em Brasília - DF. Fig. 17, diagrama da secção transversal do pecíolo do espécime coletado em São Gonçalo do Abaeté - MG. 
Tabela 1. Média do teor de umidade, cinzas totais e cinzas insolúveis em ácido clorídrico expressa em porcentagem (p/p) em folhas de P. pseudocaryophyllus (Desvio padrão e Erro Padrão da Média).

\begin{tabular}{cccc}
\hline Amostras & Umidade & Cinzas totais & Cinzas insolúveis em HCl \\
\hline I & $10,66(0,14731$ e 0,08505$)$ & $6,60(0,19466$ e 0,11238$)$ & $0,09(0,04622$ e 0,02669$)$ \\
II & $7,81(0,12619$ e 0,07286$)$ & $3,71(0,0781$ e 0,04509$)$ & $0,14(0,0115$ e 0,00664$)$ \\
III & $7,71(0,04537$ e 0,02619$)$ & $4,91(0,04801$ e 0,02772$)$ & $0,31(0,02453$ e 0,01416$)$ \\
IV & $7,11(0,03753$ e 0,02167$)$ & $4,70(0,01155$ e 0,00667$)$ & $0,49(0,01501$ e 0,00867$)$ \\
\hline
\end{tabular}

Amostra I = Folhas coletadas em Brasília - DF em período de frutificação; Amostra II = Folhas coletadas em Brasília - DF em período de floração; Amostra III = Folhas coletadas em São Gonçalo do Abaeté - MG em período de frutificação; Amostra IV = Folhas coletadas em São Gonçalo do Abaeté - MG em período de floração.

Tabela 2. Principais classes de metabólitos secundários detectados nas amostras dos espécimes de P. pseudocaryophyllus analisados.

\begin{tabular}{lcc}
\hline Classes de metabólitos secundários & Espécime de Minas Gerais & Espécime de Brasília \\
\hline Heterosídeos Antraquinônicos & Traços & Traços \\
Heterosídeos Digitálicos & Negativa & Negativa \\
Heterosídeos Flavonóides & Positiva & Positiva \\
Heterosídeos Saponínicos & Negativa & Negativa \\
Taninos & Positiva & Positiva \\
Alcalóides & Negativa & Negativa \\
Cumarinas & Negativa & Negativa \\
Óleos essenciais & Positivo & Positivo \\
\hline
\end{tabular}

Tabela 3. Média dos valores obtidos nos doseamentos de flavonóides e fenóis totais em folhas de P. pseudocaryophyllus expressos em porcentagem (p/p) (Desvio padrão e Erro Padrão da Média).

\begin{tabular}{lcc}
\hline Amostras & $\begin{array}{c}\text { Doseamento de flavonóides pelo método } \\
\text { descrito na monografia da Calêndula (F. Bras. } \\
\text { IV, 2001) }\end{array}$ & $\begin{array}{c}\text { Doseamento de Fenóis Totais pelo método de } \\
\text { Hagerman \& Butler (Mole \& Waterman, 1987a,b) }\end{array}$ \\
\hline I & $1,05^{*}(0,02318$ e 0,01338$)$ & $9,08(0,04619$ e 0,02667$)$ \\
II & $1,37^{*}(0,01528$ e 0,00882$)$ & $10,52(0,84244$ e 0,48639$)$ \\
\hline III & $0,90^{*}(0,03889$ e 0,02245$)$ & $9,77(0,43981$ e 0,25393$)$ \\
IV & $1,07^{*}(0,0611$ e 0,03528$)$ & $7,37(0,37409$ e 0,21598$)$
\end{tabular}

*Resultado fornecido em porcentagem $(\mathrm{p} / \mathrm{p})$ de flavonóides calculados como hiperosídeo $\left(\mathrm{C}_{12} \mathrm{H}_{20} \mathrm{O}_{12}\right)$. Amostra $\mathrm{I}=$ Folhas coletadas em Brasília - DF em período de frutificação; Amostra II = Folhas coletadas em Brasília - DF em período de floração; Amostra III = Folhas coletadas em São Gonçalo do Abaeté - MG em período de frutificação; Amostra IV = Folhas coletadas em São Gonçalo do Abaeté - MG em período de floração.

\section{CONCLUSÕES}

A espécie analisada, proveniente de duas localidades geográficas brasileiras, não apresentou diferenças fitoquímicas marcantes nos ensaios qualitativos. Quanto aos aspectos morfo-anatômicos da folha podem ser apontadas algumas diferenças: o padrão de nervação, apesar de ser o mesmo (camptódromo-broquidódromo), apresentou diferença no traçado dos arcos que formam a nervura marginal comum das Myrtaceae, e o pecíolo e a nervura principal apresentaram-se com diâmetros maiores no espécime de São Gonçalo do Abaeté - MG.

Cabe ressaltar a necessidade de estudos mais 
Tabela 4. Média dos valores obtidos nos doseamentos de taninos em folhas de P. pseudocaryophyllus realizados por três diferentes métodos e expressos em porcentagem (p/p) (Desvio padrão e Erro Padrão da Média).

\begin{tabular}{|c|c|c|c|c|}
\hline \multirow[t]{2}{*}{ Amostras } & \multirow[t]{2}{*}{$\begin{array}{c}\text { Método de Hagerman \& } \\
\text { Butler (Mole \& Waterman, } \\
\text { 1987a,b) }\end{array}$} & \multicolumn{2}{|c|}{$\begin{array}{l}\text { Método descrito na monografia do Barbatimão } \\
\qquad \text { (F. Bras. IV, 2002) }\end{array}$} & \multirow[t]{2}{*}{$\begin{array}{c}\text { Método descrito na } \\
\text { monografia da Espinheira } \\
\text { Santa (F. Bras. IV, 2002) }\end{array}$} \\
\hline & & Pó-de-pele & $\begin{array}{c}\text { Caseína em substituição } \\
\text { ao pó-de-pele }\end{array}$ & \\
\hline I & $5,97(0,07703$ e 0,04447$)$ & $\begin{array}{c}14,56(0,56889 \mathrm{e} \\
0,32845)\end{array}$ & $\begin{array}{c}13,08(0,08505 \mathrm{e} \\
0,0491)\end{array}$ & $2,67(0,26694$ e 0,15412$)$ \\
\hline II & $4,20(0,25115$ e 0,145$)$ & $\begin{array}{c}15,41(0,03606 \mathrm{e} \\
0,02082)\end{array}$ & $\begin{array}{c}10,86(0,06028 \mathrm{e} \\
0,0348)\end{array}$ & $5,10(0,47557$ e 0,27457$)$ \\
\hline III & $5,67(0,20019$ e 0,11558$)$ & $\begin{array}{c}14,84(1,92864 \mathrm{e} \\
1,1135)\end{array}$ & $\begin{array}{l}13,46(0,05568 \mathrm{e} \\
0,03215)\end{array}$ & $3,75(0,20578$ e 0,11881$)$ \\
\hline IV & $2,68(0,27249$ e 0,15732$)$ & $\begin{array}{c}12,08(0,12014 \mathrm{e} \\
0,06936)\end{array}$ & $\begin{array}{c}12,75(0,18502 \mathrm{e} \\
0,10682)\end{array}$ & $4,04(0,01387$ e 0,00801$)$ \\
\hline
\end{tabular}

Amostra I = Folhas coletadas em Brasília - DF em período de frutificação; Amostra II = Folhas coletadas em Brasília - DF em período de floração; Amostra III = Folhas coletadas em São Gonçalo do Abaeté - MG em período de frutificação; Amostra IV = Folhas coletadas em São Gonçalo do Abaeté - MG em período de floração.

detalhados que busquem elucidar o funcionamento do complexo secretor da lâmina foliar desta planta, bem como analisar com maior exatidão os tipos de estômatos presentes na sua superfície abaxial. Fazem-se também necessários estudos ontogenéticos para verificar a origem das células que constituem as camadas subepidémicas a fim de elucidar a ocorrência de epiderme uniestratificada, pluriestratificada ou hipoderme.

$O$ método de secagem adotado no desenvolvimento deste trabalho propiciou uma faixa de umidade para as folhas de P. pseudocaryophyllus próxima ao limite estabelecido pela Farmacopéia Brasileira IV (1988) o que propiciará uma boa conservação da droga vegetal.

Os diferentes resultados obtidos nos doseamentos chamam a atenção para a necessidade de se especificar, juntamente com o limite mínimo de taninos totais estabelecido pela monografia, o método utilizado. Desta forma, com base nos resultados obtidos, sugere-se que a matéria-prima vegetal (folha) de $P$. pseudocaryophyllus contenha, em média, 4,6\% (p/p) de taninos totais dosados pelo método de Hagerman \& Butler, $14,2 \%(\mathrm{p} / \mathrm{p})$ dosados pelo método descrito na monografia do Barbatimão e $3,9 \%(\mathrm{p} / \mathrm{p})$ dosados pelo método descrito na monografia da Espinheira Santa.

No que se refere aos fenóis totais e flavonóides sugere-se que a matéria-prima vegetal contenha, em média, $1,1 \%(\mathrm{p} / \mathrm{p})$ de flavonóides expressos como hiperosídeo e $9,1 \%(\mathrm{p} / \mathrm{p})$ de fenóis totais dosados pelo método de Hagerman e Butler.

Foram verificados indícios de variabilidade nos teores de metabólitos secundários da matériaprima vegetal de $P$. pseudocaryophyllus relacionada a fatores fenológicos e geográficos, especialmente no que se refere aos flavonóides. Fazem-se necessários, entretanto, estudos que utilizem maior amostragem, as diferentes metodologias aqui utilizadas e também outras técnicas, como as cromatográficas, a fim de se elaborar afirmações mais conclusivas.

\section{AGRADECIMENTOS}

À Fundação de Apoio à Pesquisa (FUNAPE/ UFG), à Faculdade de Farmácia /UFG, ao Instituto de Ciências Biológicas/UFG e à Universidade Estadual de Goiás (UEG).

\section{REFERÊNCIAS}

Agra MF, França PF, Barbosa-Filho JM 2007. Synopsis of the plants known as medicinal and poisonous in Northeast of Brazil. Rev Bras Farmacogn 17: 114-140.

Albuquerque UP, Hanazaki N 2006. As pesquisas etnodirigidas na descoberta de novos fármacos de interesse médico e farmacêutico: fragilidades e pespectivas. Rev Bras Farmacogn 16 (Supl.): 678-689.

Amaral ACF, Kuster RM, Bessa WS, Barnes RA, Kaplan MAC, Wessjohann LA 2001. Flavonoids and other phenolics from leaves of two Marlierea species (Myrtaceae). Biochem Syst Ecol 29: 653-654.

Amaral FMM, Ribeiro MNS, Barbosa-Filho JM, Reis AS, Nascimento FRF, Macedo RO 2006. Plants and chemical constituents with giardicidal activity. Rev Bras Farmacogn 16 (Supl.): 696-720.

Apel MA, Sobral M, Henriques AT 2006. Composição química do óleo volátil de Myrcianthes nativas da região sul do Brasil. Rev Bras Farmacogn 16: 402-407.

Barbosa-Filho JM, Medeiros KCP, Diniz MFFM, Batista LM, Athayde-Filho PF, Silva MS, Cunha EVL, Almeida JRGS, Quintans-Júnior LJ 2006a. Natural products inhibitors of the enzyme acetylcholinesterase. Rev Bras Farmacogn 16: 258-285.

Barbosa-Filho JM, Martins VKM, Rabelo LA, Moura MD, 
Silva MS, Cunha EVL, Souza MFV, Almeida RN, Medeiros IA 2006b. Natural products inhibitors of the angiotensin converting enzyme (ACE). A review between 1980-2000. Rev Bras Farmacogn 16: 421-446.

Biavatti MW, Marensi V, Leite SN, Reis A 2007. Ethnopharmacognostic survey on botanical compendia for potential cosmeceutic species from Atlantic Forest. Rev Bras Farmacogn 17: 640-653.

Borella JC, Duarte DP, Novaretti AAG, Menezes Júnior A, França SC, Rufato CB, Santos PAS, Veneziani RCS, Lopes NP 2006. Variabilidade sazonal do teor de saponinas de Baccharis trimera (Less.) DC (Carqueja) e isolamento de flavona. Rev Bras Farmacogn 16: 557-561.

Brandão MGL, Cosenza GP, Moreira RA, Monte-Mor RLM 2006. Medicinal plants and other botanical products from the Brazilian Official Pharmacopoeia. Rev Bras Farmacogn 16: 408-420.

Bukatsch F 1972. Bemerkungen zur doppelfärbung astrablausafranin. Mikrokosmos 61: 255, apud Kraus \& Arduin 1997. Manual básico de métodos em morfologia vegetal. Seropédica: Universidade Rural.

Callado CH 1993/1997. Anatomia foliar de Eugenia cuprea (Berg) NDZ. e Marlierea suaveolens Gard. (Myrtaceae). Rodriguésia 45/49: 25-37.

Cardoso CMV, Sajo MG 2004. Vascularização foliar e a identificação de espécies de Eugenia L. (Myrtaceae) da bacia hidrográfica do Rio Tibagi, PR. Rev Bras Bot 27: 47-54.

Carvalho JCT, Gosmann G, Schenkel EP 2004. Compostos fenólicos simples e heterosídicos. In: Simões CMO, Schenkel EP, Gosmann G, Mello JCP, Mentz LA, Petrovick PR (org.). Farmacognosia: da planta ao medicamento. 5. ed. rev. ampl. Florianópolis: Ed. da UFSC; Porto Alegre: Ed. da UFRGS, p. 519-535.

Costa AF 2001. Farmacognosia. 3. ed. Lisboa: Calouste Gulbenkian.

Elisabetsky E, Souza GC 2004. Etnofarmacologia como ferramenta na busca de substâncias ativas. In: Simões CMO, Schenkel EP, Gosmann G, Mello JCP, Mentz LA, Petrovick PR (org.) Farmacognosia: da planta ao medicamento. 5. ed. rev. ampl. Florianópolis: Ed. da UFSC; Porto Alegre: Ed. da UFRGS, p. 107-122.

Fapemig 2002. Plantas medicinais: o potencial de nossa flora 2002. Revista Minas Faz Ciência 11. Disponível em: $<$ http://revista.fapemig.br/>. Acessada em: 29 jan. 2005.

Farias MR 2004. Avaliação da qualidade de matérias-primas vegetais. In: Simões CMO, Schenkel EP, Gosmann G, Mello JCP, Mentz LA, Petrovick PR (org.) Farmacognosia: da planta ao medicamento. 5. ed. rev. ampl. Florianópolis: Ed. da UFSC; Porto Alegre: Ed. da UFRGS, p.263-288.

Farmacopéia Brasileira 1988. 4. ed. São Paulo: Atheneu, parte 1 .

Farmacopéia Brasileira 1996. 4. ed. São Paulo: Atheneu, parte 2. fasc. 1

Farmacopéia Brasileira 2001. 4. ed. São Paulo: Atheneu, parte 2. fasc. 3.

Farmacopéia Brasileira 2002. 4. ed. São Paulo: Atheneu, parte 2. fasc. 4.

Farmacopéia Brasileira 2003. 4. ed. São Paulo: Atheneu, parte 2. fasc. 5 .

Fernández A, Álvares A, García D, Sáenz T 2001. Antiinflammatory effect of Pimenta racemosa var. ozua and isolation of the triterpene lupeol. Il Farmaco 56: 335-338.

Fontenelle GB, Costa CG, Machado RD 1994. Foliar anatomy and micromorphology of eleven species of Eugenia L. (Myrtaceae). Bot J Linn Soc 115: 111-133.

Funari CS, Ferro VO 2005. Uso ético da biodiversidade brasileira: necessidade e oportunidade. Rev Bras Farmacogn 15: 178-182.

García MD, Fernández MA, Alvarez A, Saenz MT 2004. Antinoceptive and anti-inflammatory effect of aqueous extract from leaves of Pimenta recemosa var. ozua (Mirtaceae). J Ethnopharmacol 91: 69-73.

Gomes DMS, Neves LJ 1993/1997. Anatomia foliar de Gomidesia spectabilis (DC) Berg. e Gomidesia nitida (Vell.) Legr. (Myrtaceae). Rodriguésia 45/49: 51-70.

Gottlieb OR, Koketsu M, Moura LL, Moreira A, Magalhães MT 1970. Os óleos essenciais do Pseudocaryophyllus jaccoudii e Calyptranthes sp. An Acad Bras Cienc 42: 143-146.

Johansen DA 1940. Plant microtechnique. New York: McGraw-Hill Book, apud Kraus \& Arduin 1997. Manual básico de métodos em morfologia vegetal. Seropédica: Universidade Rural.

Joly AB 1979. Botânica: introdução à taxonomia vegetal. 5. ed. São Paulo: Companhia Editora Nacional.

Judd WS, Campbell CS, Kellogg EA, Stevens PF 1999. Plant systematics: a phylogenetic approach. Sunderland: Sinauer.

Landrum LR 1986. Monography 45: Campomanesia, Pimenta, Blepharocalyx, Legrandia, Acca, Myrrhinium, and Luma (Myrtaceae). Flora Neotropica 4: 72-115.

Landrum LR, Kawasaki ML 1997. The genera of Myrtaceae in Brazil: an illustrated synoptic treatment and identification keys. Brittonia 49: 508-536.

Lorenzi H 2002. Árvores brasileiras: manual de identificação e cultivo de plantas arbóreas do Brasil. 2. ed. Nova Odessa: Instituto Plantarum de Estudos da Flora.

Matos FJA 1997. Introdução à fitoquímica experimental. 2. ed. Fortaleza: UFC.

Matos JMD, Matos ME 1989. Farmacognosia. Fortaleza: UFC.

Metcalfe CR, Chalk L 1979. Anatomy of the dicotyledons. 2nd ed. Oxford: Clarendon Press.

Mole S, Waterman PG 1987a. A critical analysis of techniques for measuring tannins in ecological studies I. Techniques for chemically defining tannins. Oecologia 72: 137-147.

Mole S, Waterman PG 1987b. A critical analysis of techniques for measuring tannins in ecological studies II. Techniques for biochemically defining tannins. Oecologia 72: 148-156.

Monteiro JM, Albuquerque UP, Araújo EL, Amorim ELC 2005. Taninos: uma abordagem da química à ecologia. Quim Nova 28: 892-896.

Monteiro JM, Albuquerque UP, Lins Neto EMF, Araújo EL, Albuquerque MM, Amorim ELC 2006. The effects of seasonal climate changes in the Caatinga on tannin levels in Myracrodruon urundeuva (Engl.) Fr. All. and Anadenanthera colubrina (Vell.) Brenan. Rev Bras Farmacogn 16: 338-344. 
Nakaoka-Sakita M, Aguiar OT, Yatagai M, Igarashi T 1994. Óleo essencial de Pimenta pseudocaryophyllus var. pseudocaryophyllus (Gomes) Landrum (Myrtaceae) I: cromatografia a gás/espectrometria de massa (CG/ EM). Rev Inst Flor 6: 53-61.

Oliveira F, Akisue G 2000. Fundamentos de farmacobotânica. 2. ed. São Paulo: Atheneu.

Oliveira F, Akisue G, Akisue MK 1998. Farmacognosia. São Paulo: Atheneu.

Rodrigues VEG, Carvalho DA 2001. Plantas medicinais no domínio dos cerrados. Lavras: UFLA.

Santos SC, Costa WF, Batista F, Santos LR, Ferri PH, Ferreira HD, Seraphin JC 2006. Seasonal variation in the content of tannins in barks of barbatimão species. Rev Bras Farmacogn 16: 552-556.

Santos SC, Mello JCP 2004. Taninos. In: Simões CMO, Schenkel EP, Gosmann G, Mello JCP, Mentz LA, Petrovick PR (org.) Farmacognosia: da planta ao medicamento. 5. ed. rev. ampl. Florianópolis: Ed. da UFSC; Porto Alegre: Ed. da UFRGS, p. 615-656.

Silveira D, Wagner H, Chiari E, Lombardi JA, Assunção AC, Oliveira AB, Raslan DS 2005. Biological activity of the aqueous extract of Lychnophora pinaster Mart. Rev Bras Farmacogn 15: 294-297.

Solereder H 1908. Systematic anatomy of the dicotyledons: a handbook for laboratories of pure and applied botany. Oxford: Clarendon Press.

Souza VC, Lorenzi H 2005. Botânica sistemática: guiailustrado para identificação das famílias de Angiospermas da flora brasileira, baseado em APG II. Nova Odessa: Instituto Plantarum.

Suárez A, Ulate G, Ciccio JF 2000. Hypotensive action of an aqueous extract of Pimenta dioica (Myrtaceae) in rats. Rev Biol Trop 48: 53-58.

Souza TM, Moreira RRD, Pietro RCLR, Isaac VLB 2007. Avaliação da atividade anti-séptica de extrato seco de Stryphnodendron adstringens (Mart.) Coville e de preparação cosmética contendo este extrato. Rev Bras Farmacogn 17: 71-75.

The New York Botanical Garden. 2004. Disponível em: $<$ www.nybg.org/bsci/hcol/sebc/Myrtaceae.html $>$. Acessada em ago. de 2004.

WHO 1999. Monographs on selected medicinal plants. Geneva: World Health Organization.

WHO 2002. Monographs on selected medicinal plants. Geneva: World Health Organization.

Wollenweber E, Wehde R, Dörr M, Lang G, Stevens JF 2000. C-Methyl-flavonoids from the leaf waxes of some Myrtaceae. Phytochemistry 55: 965-970.

Yunes RA, Pedrosa RC, Cechinel-Filho V 2001. Fármacos e fitoterápicos: a necessidade do desenvolvimento da indústria de fitoterápicos e fitofármacos no Brasil. Quim Nova 24: 147-152.

Zuanazzi JAS, Montanha JA 2004. Flavonóides. In: Simões CMO, Schenkel EP, Gosmann G, Mello JCP, Mentz LA, Petrovick PR (org.) Farmacognosia: da planta ao medicamento. 5. ed. rev. ampl. Florianópolis: Ed. da UFSC; Porto Alegre: Ed. da UFRGS, p.577-614. 